\title{
High-Surface-Area, Iron-Oxide Films Prepared by Atomic Layer Deposition on $\gamma-\mathrm{Al}_{2} \mathrm{O}_{3}$
}

Tzia Ming Onn ${ }^{a}$, Matteo Monai ${ }^{b}$, Sheng Dai ${ }^{c}$, Lisandra Arroyo-Ramirez ${ }^{\text {a }}$, Shuyi Zhang ${ }^{c}$,

Xiaoqing Pan ${ }^{c, d}$, George W. Graham ${ }^{c}$, Paolo Fornasiero ${ }^{b}$, Raymond J. Gorte ${ }^{\mathrm{a},{ }^{*}}$.

*Corresponding Author, Email: gorte@ seas.upenn.edu

\section{Abstract:}

High-surface-area iron oxides were prepared by Atomic Layer Deposition (ALD) on 130$\mathrm{m}^{2} / \mathrm{g} \gamma-\mathrm{Al}_{2} \mathrm{O}_{3}$ for use as a catalyst support. Measurements of the sample mass, surface area, and pore-size distribution as a function of the number of ferrocene- $\mathrm{O}_{2}$ ALD cycles at $623 \mathrm{~K}$ suggested that the iron oxide grew as a dense, conformal film with a growth rate similar to 0.016-nm per cycle. While films with 20 ALD cycles $\left(20 \mathrm{Fe}_{2} \mathrm{O}_{3}-\mathrm{Al}_{2} \mathrm{O}_{3}, 0.25 \mathrm{~g} \mathrm{Fe}_{2} \mathrm{O}_{3} / \mathrm{g} \mathrm{Al}_{2} \mathrm{O}_{3}\right)$ were difficult to distinguish by HAADF STEM, EDS mapping indicated the $\mathrm{Al}_{2} \mathrm{O}_{3}$ was uniformly coated. Raman Spectroscopy showed the films were in the form of $\mathrm{Fe}_{2} \mathrm{O}_{3}$; but XRD measurements on samples with as many as 100 ALD cycles $\left(100 \mathrm{Fe}_{2} \mathrm{O}_{3}-\mathrm{Al}_{2} \mathrm{O}_{3}, 0.84 \mathrm{~g} \mathrm{Fe}_{2} \mathrm{O}_{3} / \mathrm{g}\right.$ $\mathrm{Al}_{2} \mathrm{O}_{3}$ ) showed no evidence for crystalline iron-oxide phases, even after calcination at $1073 \mathrm{~K}$. Specific rates for the water-gas-shift (WGS) reaction on the ALD-coated samples were significantly lower than those on bulk $\mathrm{Fe}_{2} \mathrm{O}_{3}$. However, addition of 1 wt.\% Pd to $\mathrm{Fe}_{2} \mathrm{O}_{3} / \mathrm{Al}_{2} \mathrm{O}_{3}$ supports prepared by ALD exhibited specific rates that were much higher than that observed when 1 wt.\% $\mathrm{Pd}$ was added to $\mathrm{Fe}_{2} \mathrm{O}_{3} / \mathrm{Al}_{2} \mathrm{O}_{3}$ prepared by conventional impregnation of Fe salts, suggesting more uniform contact between the $\mathrm{Pd}$ and $\mathrm{FeO}_{\mathrm{x}}$ phases on samples prepared by ALD.

Keywords: Iron Oxide, Atomic Layer Deposition, Palladium, Water Gas Shift, Redox Properties, Thermal Stability 


\section{Introduction:}

Reducible oxides are of great interest as both catalysts and as functional catalyst supports. An important example of this is ceria-zirconia mixed oxides, which are used as the oxygenstorage component in automotive, three-way catalysts [1,2]. Another is iron oxide, which is used as a high-temperature, water-gas-shift (WGS) catalyst, either by itself or together with a metal promoter, such as $\mathrm{Cu}[3,4], \mathrm{Ru}[5,6]$, or $\mathrm{Pd}$ [7]. Iron oxide has also been reported to promote other reactions when used as a support [8-14]. A major problem with these and other reducible oxides is that their surface areas tend to be low and to decrease with time. A typical surface area for ceria-zirconia mixed oxides under working conditions is only $2 \mathrm{~m}^{2} / \mathrm{g}$ [15]. Commercial ironoxide, WGS catalysts can have initial surface areas between 30 and $100 \mathrm{~m}^{2} / \mathrm{g}$ due to the addition of $\mathrm{Cr}_{2} \mathrm{O}_{3}$ or $\mathrm{Al}_{2} \mathrm{O}_{3}$ structural promoters; but loss of iron-oxide surface area remains a major cause for deactivation [16]. Furthermore, chromia toxicity is a cause for concern during catalyst manufacture and handling, so that there would be benefits to avoiding its use [16].

A common strategy for achieving high-surface-area functional oxides is to disperse them on a more stable support, such as alumina or zirconia $[17,18]$. When these functional oxides are added by conventional impregnation, they tend to form larger crystallites, so that the actual active surface area may not be greatly enhanced. However, some of us have recently shown that uniform, thin ceria or zirconia films can be deposited onto high-surface-area alumina by Atomic Layer Deposition (ALD) [19,20]. These films showed remarkable thermal stability, apparently due to interactions between the alumina and the supported oxides. Furthermore, when the ALDprepared, ceria-alumina was used as a support for Pd, the catalytic activities for WGS and COoxidation reactions were similar to that of a $\mathrm{Pd} /$ ceria catalyst, but with much better thermal stability. These results suggest that it may be possible to prepare composite supports for other oxides, such as iron oxide.

In ALD, an organometallic precursor is first allowed to react with the substrate, alumina in our case, at a temperature below that at which Chemical Vapor Deposition occurs. Reaction stops at the monolayer coverage because the precursor does not react with itself. After removing excess precursor from the gas phase, the adsorbed precursor is oxidized. A film of desired thickness is prepared by repeating this cycle as many times as desired [21,22]. With high-surface area supports, the practical film thickness cannot be greater than one or two nanometers. For example, the $\mathrm{Fe}_{2} \mathrm{O}_{3}$ loading corresponding to a 1-nm film with bulk properties on a $100 \mathrm{~m}^{2} / \mathrm{g}$ 
substrate would be $0.52 \mathrm{~g} \mathrm{Fe}_{2} \mathrm{O}_{3} / \mathrm{g}$ of substrate. Even if decreases in pore size were not an issue, the added mass of the sample would significantly decrease the specific surface area of the catalyst.

In the present work, we investigated the formation and catalytic properties of $\mathrm{FeO}_{\mathrm{x}}$ films prepared by $\mathrm{ALD}$ on a high-surface-area $\mathrm{Al}_{2} \mathrm{O}_{3}$. We demonstrate that growth of conformal oxide films is possible when ALD is performed in a static system. Furthermore, these films can be used as high-surface area supports for metal catalysts.

\section{Experimental Methods:}

The high-surface-area, iron-oxide films were prepared by ALD using a home-built apparatus that has been described in detail previously [23,24]. The apparatus is essentially a high-temperature adsorption system that can be evacuated with a mechanical vacuum pump to approximately $10^{-3}$ Torr. It consists of two chambers, one containing the ferrocene $\left(\mathrm{Fe}(\mathrm{Cp})_{2}\right.$, Sigma Aldrich) precursor and the other the $\mathrm{Al}_{2} \mathrm{O}_{3}$ substrate. These chambers were separated from each other and from the vacuum pump and an $\mathrm{O}_{2}$ source by high-temperature valves. The chamber containing the $\mathrm{Al}_{2} \mathrm{O}_{3}$ substrate is a quartz tube with dimensions 0.25 inch in diameter and 3 inch in length. The deposition conditions were adopted from previous publications [25]. After evacuating the chamber containing the $\mathrm{Fe}(\mathrm{Cp})_{2}$ precursor at room temperature, it was heated to $393 \mathrm{~K}$ to produce a $\mathrm{Fe}(\mathrm{Cp})_{2}$ vapor pressure of about 5 Torr. During the deposition cycle, the $\mathrm{Fe}(\mathrm{Cp})_{2}$ vapor was introduced to the evacuated sample chamber, which contained approximately $0.5 \mathrm{~g} \mathrm{Al}_{2} \mathrm{O}_{3}$. The alumina substrate was exposed to the precursor vapor at $623 \mathrm{~K}$ for $300 \mathrm{~s}$ to ensure that reaction with the surface was complete but pressure changes indicated that adsorption was complete in about $10 \mathrm{~s}$. In one experiment, the growth rate was shown to be unchanged when the sample was exposed to $\mathrm{Fe}(\mathrm{Cp})_{2}$ vapor, then evacuated, multiple times between oxidation steps. After evacuation, the alumina substrate was oxidized by exposing it to 200 Torr of $\mathrm{O}_{2}$ for $300 \mathrm{~s}$. The high temperature was required primarily to ensure that the adsorbed precursor was completely oxidized upon exposure to $\mathrm{O}_{2}$. Throughout this paper, ALDprepared samples will be designated by the number of ALD cycles that were used, e.g. $40 \mathrm{Fe}_{2} \mathrm{O}_{3}$ $\mathrm{Al}_{2} \mathrm{O}_{3}$ refers to a sample exposed to $40 \mathrm{Fe}(\mathrm{Cp})_{2}-\mathrm{O}_{2}$ cycles.

The alumina substrate in this study was a $\gamma-\mathrm{Al}_{2} \mathrm{O}_{3}$ (Strem Chemicals, Inc.), stabilized by calcination in air to $1173 \mathrm{~K}$ for $24 \mathrm{~h}$. The BET surface area after this pretreatment was $130 \mathrm{~m}^{2} / \mathrm{g}$. 
A bulk $\mathrm{Fe}_{2} \mathrm{O}_{3}$ powder was prepared by precipitating an aqueous solution of $\mathrm{Fe}\left(\mathrm{NO}_{3}\right)_{3} \cdot 9 \mathrm{H}_{2} \mathrm{O}$ with excess ammonium hydroxide $\left(\mathrm{NH}_{4} \mathrm{OH}\right.$, Fisher Scientific), followed by calcination to $673 \mathrm{~K}$ for 6 h. For comparison to ALD-prepared samples, we also prepared a $\mathrm{Fe}_{2} \mathrm{O}_{3}(\mathrm{IMP}) / \mathrm{Al}_{2} \mathrm{O}_{3}$ sample by impregnation of $\mathrm{Fe}\left(\mathrm{NO}_{3}\right)_{3} \cdot 9 \mathrm{H}_{2} \mathrm{O}$, followed by calcination to $673 \mathrm{~K}$ for $6 \mathrm{~h}$ to remove all nitrates. Catalysts containing $1 \mathrm{wt}$ \% Pd were synthesized by incipient wetness using aqueous solutions of tetraaminepalladium(II) nitrate (Sigma Aldrich). Metal-containing catalysts were dried overnight at $333 \mathrm{~K}$ and calcined at $773 \mathrm{~K}$ in air for $6 \mathrm{~h}$ to remove any organics and nitrates.

The Pd dispersions were determined volumetrically using $\mathrm{CO}$ adsorption uptakes at room temperature. In all cases, the samples were pretreated by oxidation in 200 Torr $\mathrm{O}_{2}$ at $673 \mathrm{~K}$, followed by reduction in 200 Torr $\mathrm{H}_{2}$ at $423 \mathrm{~K}$. To characterize film growth during ALD, we measured the sample weights and BET surface areas as a function of the number of ALD cycles using $\mathrm{N}_{2}$ adsorption at $78 \mathrm{~K}$ in a home-built adsorption system. Pore-size distribution measurements on a few selected samples were obtained from $\mathrm{N}_{2}$ adsorption-desorption isotherms at $78 \mathrm{~K}$ using a Micrometrics ASAP 2020 system. X-Ray Diffraction (XRD) patterns were recorded on a Rigaku Smartlab diffractometer equipped with a $\mathrm{Cu} \mathrm{Ka}$ source $(\lambda=0.15416 \mathrm{~nm})$. The elemental compositions of selected samples were measured by Inductively Coupled Plasma-Optical Emission Spectrometry (ICP-OES) performed on a Spectro Genesis spectrometer with a concentric nebulizer. For the ICP-OES measurement, each sample $(\sim 50 \mathrm{mg})$ was dissolved in a $5 \mathrm{~mL}$ solution of Aqua Regia overnight. The solutions were then diluted with a $10 \mathrm{wt} . \% . \mathrm{HNO}_{3}$ solution to the appropriate concentration before the ICP analysis.

Ex-situ scanning transmission electron microscopy (STEM) was performed on powder specimens that had been sonicated in methanol and dropped onto carbon support films on copper TEM grids (Ted Pella, Inc.) for TEM examination. Specimens were initially examined with a JEOL 3100R05 electron microscope with double spherical aberration-correctors operated at 300 $\mathrm{kV}$. Subsequently, elemental mapping via energy dispersive X-ray spectroscopy (EDS) was performed with a JEOL 2800 STEM, operated at $200 \mathrm{kV}$, with a large angle dual dry solid-state $100 \mathrm{~mm}^{2}$ detector. Raman spectra were recorded with an Invia Renishaw microspectrometer equipped with $\mathrm{He}-\mathrm{Ne}$ laser at $532 \mathrm{~nm}$. Raman measurements were carried out with a laser power of $1 \mathrm{~mW}$ at the sample and a collection time of $20 \mathrm{~s}$. At least 5 spectra per sample were recorded in order to check the uniformity of the materials. 
Steady-state water-gas-shift reaction rates were measured in a 0.25 inch, quartz, tubular reactor, using $\mathrm{He}$ as the carrier gas, with partial pressures of $\mathrm{CO}$ and $\mathrm{H}_{2} \mathrm{O}$ both at 25 Torr (3.3\%). The total flow rate of He was kept at $60 \mathrm{~mL} / \mathrm{min}$. Before testing, each sample was activated by heating the catalysts to $673 \mathrm{~K}$ in the reaction mixture before cooling back to the desired reaction temperature. The mass of catalyst used in every rate measurement was $0.10 \mathrm{~g}$ and the products were analyzed using a gas chromatograph (SRI8610C) equipped with a Hayesep Q column and a TCD detector. Differential conversions were maintained in all cases, and the rates were normalized to the mass of the catalyst.

Transient pulse experiments were performed using equipment that has been described elsewhere [26]. The system consists of a tubular reactor equipped with computer-controlled solenoid valves to allow step changes in the composition of the inlet gases. Reactant gases were passed over $200 \mathrm{mg}$ samples in a 0.25 inch quartz tube. The reactor effluent was monitored continuously using an online quadrupole mass spectrometer. The total flow rate of the He carrier gas was kept constant at $25 \mathrm{~mL} / \mathrm{min}$, while the concentrations of the reactive component (either $\mathrm{CO}$ or $\mathrm{O}_{2}$ ) was chosen to be $10 \%$ of the total gas stream. Integration of the partial pressures as a function of time allowed accurate determination of the amounts of $\mathrm{CO}_{2}$ formed during a $\mathrm{CO}$ pulse. Prior to taking the pulse data, the samples were treated in $10 \% \mathrm{O}_{2}$ at $673 \mathrm{~K}$ for $15 \mathrm{~min}$. This treatment was followed by reduction in $10 \% \mathrm{CO}$ at $673 \mathrm{~K}$ for $10 \mathrm{~min}$ and then re-oxidation in $10 \% \mathrm{O}_{2}$ for an additional $15 \mathrm{~min}$. No attempt was made to analyze the shapes of the pulses because coupling between desorption, re-adsorption, reaction, and diffusion does not allow for a unique determination of rate processes in transient experiments of this type.

\section{Results:}

\section{Characterization of $\mathrm{Fe}_{2} \mathrm{O}_{3}$ films on $\mathrm{Al}_{2} \mathrm{O}_{3}$}

The growth of the $\mathrm{Fe}_{2} \mathrm{O}_{3}$ film was first characterized by measuring the changes in the mass and BET surface area of samples as a function of the number of $\mathrm{Fe}(\mathrm{Cp})_{2}-\mathrm{O}_{2}, \mathrm{ALD}$ cycles, with the mass increase shown in Figure 1(a) and the surface areas reported in Figure 1(b). The mass of the iron-oxide films increased with the number of cycles for $\mathrm{N}<50$, but the growth rate decreased at higher coverages. To ensure that the added mass was due to $\mathrm{Fe}_{2} \mathrm{O}_{3}$, the composition of the samples was verified by ICP-OES. Assuming that $\mathrm{Fe}_{2} \mathrm{O}_{3}$ forms a dense, uniform film with 
bulk density in the low coverage regime, the initial weight gain per cycle corresponded to a growth rate of $0.016 \mathrm{~nm} /$ cycle. This value is similar to that reported in the literature for the growth rate of $\mathrm{Fe}_{2} \mathrm{O}_{3}$ using $\mathrm{Fe}(\mathrm{Cp})_{2}$ on flat surfaces [27]. After 100 cycles, the $\mathrm{Fe}(\mathrm{Cp})_{2}$ uptakes dropped to near zero, implying that we were not able to grow $\mathrm{Fe}_{2} \mathrm{O}_{3}$ films beyond that point.

Figure 1(b) demonstrates that the surface area of the sample decreased in a regular manner with the number of ALD cycles. Initially, most of the loss in specific surface area was due to the increase in sample mass. For example, after 20 ALD cycles, the mass increase was roughly $0.25 \mathrm{~g} \mathrm{Fe}_{2} \mathrm{O}_{3} / \mathrm{g} \mathrm{Al}_{2} \mathrm{O}_{3}$ and the specific surface area decreased from $130 \mathrm{~m}^{2} / \mathrm{g}$ to $93 \mathrm{~m}^{2} / \mathrm{g}$. The mass increase alone would change the specific surface area to $104 \mathrm{~m}^{2} / \mathrm{g}\left(130 \mathrm{~m}^{2} / 1.25 \mathrm{~g}\right)$ and the additional decrease is likely due to a decrease in average pore radius. However, after 100 cycles, the same point at which $\mathrm{Fe}(\mathrm{Cp})_{2}$ uptakes stopped, there was a dramatic decrease in specific surface area to $3 \mathrm{~m}^{2} / \mathrm{g}$. Since the entire pore volume cannot have been filled with $\mathrm{Fe}_{2} \mathrm{O}_{3}$, the entrance to the nanopores must have been blocked after 100 cycles, making any internal volume inaccessible to either $\mathrm{N}_{2}$ or $\mathrm{Fe}(\mathrm{Cp})_{2}$. That this was the case was further demonstrated by the fact that calcination of this sample in air to $1073 \mathrm{~K}$ restored the surface area from $3 \mathrm{~m}^{2} / \mathrm{g}$ to $70 \mathrm{~m}^{2} / \mathrm{g}$. Apparently, high-temperature treatment caused some sintering which opened these smaller pores. It is interesting to notice that high-temperature calcination of the $20 \mathrm{Fe}_{2} \mathrm{O}_{3}-\mathrm{Al}_{2} \mathrm{O}_{3}$ sample had only small effect on the surface area, increasing from 93 to $102 \mathrm{~m}^{2} / \mathrm{g}$. This would argue that there is only minimal porosity in the deposited $\mathrm{FeO}_{\mathrm{x}}$ films.

To further understand how the ALD films affect the mesopores, the pore-size distributions were measured from the $\mathrm{N}_{2}$ adsorption isotherm for samples after deposition of 0 , 10, 20, and 40 ALD cycles. The isotherms are shown in the Supporting Information section, Figure S1, while average pore sizes and pore size distributions are reported in Table 1 and Figure 2. All the samples showed type IV isotherms, with a bimodal trend, which is most evident for the calcined $\mathrm{Al}_{2} \mathrm{O}_{3}$. With the exception of the loss of very large, $\sim 30$-nm pores that were present on the initial $\mathrm{Al}_{2} \mathrm{O}_{3}$, there were no dramatic changes in the pore sizes with either increasing calcination temperature or increasing number of ALD cycles. The peak in pore-size distribution for the starting $\mathrm{Al}_{2} \mathrm{O}_{3}$ occurred at $9.6 \mathrm{~nm}$ and decreased to $8.5 \mathrm{~nm}$ on the $40 \mathrm{Fe}_{2} \mathrm{O}_{3}-\mathrm{Al}_{2} \mathrm{O}_{3}$ sample. From the weight increase after 40 ALD cycles, a uniform, dense $\mathrm{Fe}_{2} \mathrm{O}_{3}$ film would be $0.72 \mathrm{~nm}$ thick, so that cylindrical pores should decrease from $9.6 \mathrm{~nm}$ to $8.4 \mathrm{~nm}$, in reasonable agreement with our experimental observations. 
XRD results for selected samples are shown in Figure 3, together with the expected peak positions for $\alpha-\mathrm{Fe}_{2} \mathrm{O}_{3}$ at the bottom. The pattern for the unmodified $\mathrm{Al}_{2} \mathrm{O}_{3}$ is shown in Figure 3(a) for reference, while diffraction patterns for samples prepared by ALD with low $\left(20 \mathrm{Fe}_{2} \mathrm{O}_{3^{-}}\right.$ $\left.\mathrm{Al}_{2} \mathrm{O}_{3}, 0.25 \mathrm{~g} \mathrm{Fe}_{2} \mathrm{O}_{3} / \mathrm{g} \mathrm{Al}_{2} \mathrm{O}_{3}\right)$ and high coverages $\left(100 \mathrm{Fe}_{2} \mathrm{O}_{3}-\mathrm{Al}_{2} \mathrm{O}_{3}, 0.84 \mathrm{~g} \mathrm{Fe}_{2} \mathrm{O}_{3} / \mathrm{g} \mathrm{Al}_{2} \mathrm{O}_{3}\right)$, calcined in air to $1073 \mathrm{~K}$, are shown in Figures 3(b) and 3(c). Even with the addition of these large amounts of $\mathrm{Fe}_{2} \mathrm{O}_{3}$, there are no obvious diffraction features that can be associated with the Fe. For comparison, Figure 3(d) shows the XRD pattern for the $\mathrm{Fe}_{2} \mathrm{O}_{3}(\mathrm{IMP}) / \mathrm{Al}_{2} \mathrm{O}_{3}$ sample, prepared by impregnation to have $0.84 \mathrm{~g} \mathrm{Fe}_{2} \mathrm{O}_{3} / \mathrm{g} \mathrm{Al}_{2} \mathrm{O}_{3}$, similar to the high-loading ALD sample. The XRD pattern of the impregnated sample showed clear features associated with $\alpha$ $\mathrm{Fe}_{2} \mathrm{O}_{3}$ after calcination to $1073 \mathrm{~K}$. With the ALD-prepared samples, the films are apparently thinner than the coherence length of the x-rays, while the results for the impregnated sample are consistent with the formation of relatively large crystallites.

Additional evidence for the formation of thin films in the ALD-prepared samples came from High Angle Annular Dark Field (HAADF) STEM imaging and EDS elemental mapping, shown in Figure 4. Results are shown for samples with $0.25 \mathrm{~g} \mathrm{Fe}_{2} \mathrm{O}_{3} / \mathrm{g} \mathrm{Al}_{2} \mathrm{O}_{3}$ made by infiltration, $\left(\mathrm{Fe}_{2} \mathrm{O}_{3}(\mathrm{IMP}) / \mathrm{Al}_{2} \mathrm{O}_{3}\right.$, Figure 4(a)), and by $\mathrm{ALD}\left(20 \mathrm{Fe}_{2} \mathrm{O}_{3}-\mathrm{Al}_{2} \mathrm{O}_{3}\right.$, Figure 4(b)). Due to the small difference in the atomic number between Fe and Al, HAADF images alone were not sufficient to clearly show how $\mathrm{Fe}$ is distributed on the $\mathrm{Al}_{2} \mathrm{O}_{3}$ in either case, even when using the aberration-corrected STEM (see Figure S2 in Supporting Information). However, EDS elemental maps for $\mathrm{Al}, \mathrm{Fe}$, and $\mathrm{O}$ confirmed that relatively large $\mathrm{Fe}_{2} \mathrm{O}_{3}$ agglomerates were present on the infiltrated sample while thin layers of $\mathrm{Fe}$ appeared to uniformly coat $\mathrm{Al}_{2} \mathrm{O}_{3}$ for the ALD-coated sample (See Figure S3 in Supporting Information for overlaid elemental mapping of Al and Fe.).

Raman spectra, shown in Figure 5, provided additional evidence about how the $\mathrm{FeO}_{\mathrm{x}}$ films evolved with coverage. The spectra in Figures 5(a) to 5(c) were obtained on samples prepared by ALD with 10, 20, and 50 cycles, while the spectrum in Figure 5(d) was obtained from the $\mathrm{Fe}_{2} \mathrm{O}_{3}(\mathrm{IMP}) / \mathrm{Al}_{2} \mathrm{O}_{3}$ sample prepared by impregnation with $0.25-\mathrm{g} \mathrm{Fe}_{2} \mathrm{O}_{3} / \mathrm{g}_{2} \mathrm{O}_{3}$. Each of the samples was calcined to $773 \mathrm{~K}$. The sample with $10 \mathrm{ALD}$ cycles, $10 \mathrm{Fe}_{2} \mathrm{O}_{3}-\mathrm{Al}_{2} \mathrm{O}_{3}$, exhibited only a single, sharp band at $250 \mathrm{~cm}^{-1}$, which is also the most intense band observed for lepidocrocite. This suggests that the very thin ALD film retained a $\gamma-\mathrm{FeO}(\mathrm{OH})$ structure even after calcination to $773 \mathrm{~K}$. By comparison, the Raman spectra of the ALD-prepared samples with higher $\mathrm{Fe}_{2} \mathrm{O}_{3}$ coverages, $20 \mathrm{Fe}_{2} \mathrm{O}_{3}-\mathrm{Al}_{2} \mathrm{O}_{3}$ and $50 \mathrm{Fe}_{2} \mathrm{O}_{3}-\mathrm{Al}_{2} \mathrm{O}_{3}$, along with the impregnated sample, 
$\mathrm{Fe}_{2} \mathrm{O}_{3}(\mathrm{IMP}) / \mathrm{Al}_{2} \mathrm{O}_{3}$, all exhibit broad bands at 365, 720-730 and 1390-1430 $\mathrm{cm}^{-1}$. These peaks are consistent with the formation of $\gamma-\mathrm{Fe}_{2} \mathrm{O}_{3}$ (maghemite) $[28,29]$. (The presence of $\alpha-\mathrm{Fe}_{2} \mathrm{O}_{3}$ in the XRD measurements of an impregnated sample was likely due to the higher calcination temperature used in those measurements.)

\section{Catalytic Properties:}

Since $\mathrm{Fe}_{3} \mathrm{O}_{4}$ is the catalytically active phase in high-temperature WGS catalysts, we examined how modification of the $\mathrm{Al}_{2} \mathrm{O}_{3}$ support by ALD of $\mathrm{Fe}_{2} \mathrm{O}_{3}$ at different coverages compares to bulk $\mathrm{Fe}_{2} \mathrm{O}_{3}$ and a conventional supported catalyst, $\mathrm{Fe}_{2} \mathrm{O}_{3}(\mathrm{IMP}) / \mathrm{Al}_{2} \mathrm{O}_{3}$. Figure 6 shows specific rates, measured under differential conditions at 25 Torr each of $\mathrm{H}_{2} \mathrm{O}$ and $\mathrm{CO}$, as a function of temperature for bulk $\mathrm{Fe}_{2} \mathrm{O}_{3}, \mathrm{Fe}_{2} \mathrm{O}_{3}$ (IMP)/ $/ \mathrm{Al}_{2} \mathrm{O}_{3}$ with $0.13 \mathrm{~g} \mathrm{Fe}_{2} \mathrm{O}_{3} / \mathrm{g}_{2} \mathrm{O}_{3}$, and two ALD-prepared samples, $10 \mathrm{Fe}_{2} \mathrm{O}_{3}-\mathrm{Al}_{2} \mathrm{O}_{3}$ and $40 \mathrm{Fe}_{2} \mathrm{O}_{3}-\mathrm{Al}_{2} \mathrm{O}_{3}$. Rates have been normalized to the BET surface areas, which were $41 \mathrm{~m}^{2} / \mathrm{g}$ for bulk $\mathrm{Fe}_{2} \mathrm{O}_{3}, 110 \mathrm{~m}^{2} / \mathrm{g}$ for $\mathrm{Fe}_{2} \mathrm{O}_{3}$ (IMP)/ $\mathrm{Al}_{2} \mathrm{O}_{3}, 104$ $\mathrm{m}^{2} / \mathrm{g}$ for $10 \mathrm{Fe}_{2} \mathrm{O}_{3}-\mathrm{Al}_{2} \mathrm{O}_{3}$, and $77 \mathrm{~m}^{2} / \mathrm{g}$ for $40 \mathrm{Fe}_{2} \mathrm{O}_{3}-\mathrm{Al}_{2} \mathrm{O}_{3}$. While we expect the exposed surfaces of the ALD-prepared samples to consist of iron oxide, a significant fraction of the exposed surface on the $\mathrm{Fe}_{2} \mathrm{O}_{3}(\mathrm{IMP}) / \mathrm{Al}_{2} \mathrm{O}_{3}$ sample will almost certainly be alumina, so that this normalization will underestimate the specific activity of the $\mathrm{FeO}_{\mathrm{x}}$ on that sample.

Bulk $\mathrm{Fe}_{2} \mathrm{O}_{3}$ showed by far the highest specific rates, roughly ten times higher than those on the $\mathrm{Fe}_{2} \mathrm{O}_{3}(\mathrm{IMP}) / \mathrm{Al}_{2} \mathrm{O}_{3}$ sample and 20 times higher than that on the $10 \mathrm{Fe}_{2} \mathrm{O}_{3}-\mathrm{Al}_{2} \mathrm{O}_{3}$ sample. The lower specific rates on $\mathrm{Fe}_{2} \mathrm{O}_{3}$ (IMP)/ $/ \mathrm{Al}_{2} \mathrm{O}_{3}$ can be explained by the fact that only a fraction of the surface area is $\mathrm{FeO}_{\mathrm{x}}$; however, this cannot explain the lower rates on the ALD-prepared samples. It has been reported that the active sites on $\mathrm{Fe}_{3} \mathrm{O}_{4}$ correspond to $\mathrm{Fe}^{3+}-\mathrm{Fe}^{2+}$ pairs [30]; therefore, it is possible that the concentration of these sites is lower in two-dimensional films. For example, one study of supported $\mathrm{Fe}_{2} \mathrm{O}_{3}$ particles reported that the $\mathrm{Fe}_{2} \mathrm{O}_{3}-\mathrm{Fe}_{3} \mathrm{O}_{4}$ equilibrium shifted to higher $\mathrm{P}\left(\mathrm{O}_{2}\right)$ on supported particles [17]. The fact that specific rates were higher on the $40 \mathrm{Fe}_{2} \mathrm{O}_{3}-\mathrm{Al}_{2} \mathrm{O}_{3}$ compared to $10 \mathrm{Fe}_{2} \mathrm{O}_{3}-\mathrm{Al}_{2} \mathrm{O}_{3}$ suggests that the catalytic activity may increase as one approaches bulk conditions. It is important to recognize that the WGS reaction on $\mathrm{Fe}_{3} \mathrm{O}_{4}$ is complex and affected by various factors [30], a fact that is demonstrated here. As shown in Table 2, the specific rates on bulk $\mathrm{Fe}_{2} \mathrm{O}_{3}$ increased by a factor of 10 after calcination $1073 \mathrm{~K}$. Clearly, WGS rates on $\mathrm{Fe}_{2} \mathrm{O}_{3}$-based catalysts are not a simple function of surface area. 
Because WGS rates could depend on the detailed surface structure, a possibly better indication of the fraction $\mathrm{FeO}_{\mathrm{x}}$ exposed at the catalyst surface is obtained by measuring WGS rate after impregnation of 1 wt.\% $\mathrm{Pd}$. Contact between $\mathrm{Pd}$ and $\mathrm{FeO}_{\mathrm{x}}$ results in reaction rates that are much higher than those observed on either $\mathrm{Pd} / \mathrm{Al}_{2} \mathrm{O}_{3}$ or $\mathrm{FeO}_{\mathrm{x}}$ catalysts individually [7], so that reaction must occur at the $\mathrm{Pd}-\mathrm{FeO}_{\mathrm{x}}$ interface. This in turn implies that ALD-prepared catalysts should be more effective if all of the surface consists of $\mathrm{FeO}_{\mathrm{x}}$. This is indeed the case, as shown in Figure 7. Because reaction is expected to occur at the interface between $\mathrm{Pd}$ and $\mathrm{FeO}_{\mathrm{x}}$ and the $\mathrm{Pd}$ dispersions in all $\mathrm{Fe}_{2} \mathrm{O}_{3}$-containing samples were similar (See Table 3) when the samples were initially calcined to $773 \mathrm{~K}$, rates for these catalysts have been normalized to the mass of the catalysts, since each contained $1 \mathrm{wt} . \% \mathrm{Pd}$. Also, because the Pd-containing samples were so much more active, rates were measured at lower temperatures. For calcination at $773 \mathrm{~K}$, specific rates on 1 wt.\% $\mathrm{Pd}$ on $20 \mathrm{Fe}_{2} \mathrm{O}_{3}-\mathrm{Al}_{2} \mathrm{O}_{3}$ were essentially identical to those on $\mathrm{Pd} / \mathrm{Fe}_{2} \mathrm{O}_{3}$, implying that all of the $\mathrm{Pd}$ is in contact with $\mathrm{Fe}_{2} \mathrm{O}_{3}$ in both cases. Rates for $\mathrm{Pd} / \mathrm{Al}_{2} \mathrm{O}_{3}$ were roughly a factor of 10 lower, with those on $\mathrm{Pd} / \mathrm{Fe}_{2} \mathrm{O}_{3}$ (IMP)/ $/ \mathrm{Al}_{2} \mathrm{O}_{3}$ (with $0.25 \mathrm{~g} \mathrm{Fe}_{2} \mathrm{O}_{3} / \mathrm{g} \mathrm{Al}_{2} \mathrm{O}_{3}$ ) in between. The lower rates for $\mathrm{Pd} / \mathrm{Fe}_{2} \mathrm{O}_{3}(\mathrm{IMP}) / \mathrm{Al}_{2} \mathrm{O}_{3}$ are consistent with much of the $\mathrm{Pd}$ not being in contact with $\mathrm{FeO}_{\mathrm{x}}$ despite having a similar Pd dispersion.

Calcination to $1073 \mathrm{~K}$ had little effect on the $1 \mathrm{wt} \% \mathrm{Pd} / 20 \mathrm{Fe}_{2} \mathrm{O}_{3}-\mathrm{Al}_{2} \mathrm{O}_{3}$ because the surface area of the ALD sample and its $\mathrm{Pd}$ dispersions were maintained, while rates on $\mathrm{Pd} / \mathrm{Fe}_{2} \mathrm{O}_{3}$ decreased by a factor of about two due to the fact that the BET surface area dropped from 41 $\mathrm{m}^{2} / \mathrm{g}$ to $2 \mathrm{~m}^{2} / \mathrm{g}$ and its $\mathrm{Pd}$ dispersion dropped from $9 \%$ to $2 \%$. This decrease in activity is not proportional to the decrease in surface area and Pd dispersion, which implies that other factors affect WGS for catalysts based on bulk $\mathrm{Fe}_{2} \mathrm{O}_{3}$ [30]. Rates on $\mathrm{Pd} / \mathrm{Fe}_{2} \mathrm{O}_{2}(\mathrm{IMP}) / \mathrm{Al}_{2} \mathrm{O}_{3}$ decreased dramatically, presumably due to further loss in interfacial contact between the Pd and the iron oxide component of the support.

To verify $\mathrm{Fe}_{2} \mathrm{O}_{3}$ films prepared by ALD are reducible, CO-O $\mathrm{O}_{2}$ pulse measurements were performed on the 1 wt. $\% \quad \mathrm{Pd} / \mathrm{Al}_{2} \mathrm{O}_{3}, \quad 1$ wt. $\% \quad \mathrm{Pd} / 20 \mathrm{Fe}_{2} \mathrm{O}_{3}-\mathrm{Al}_{2} \mathrm{O}_{3}$, and 1 wt. $\%$ $\mathrm{Pd} / \mathrm{Fe}_{2} \mathrm{O}_{3}$ (IMP) $/ \mathrm{Al}_{2} \mathrm{O}_{3}$ (with the same $\mathrm{Fe}_{2} \mathrm{O}_{3}$ loading as the $20 \mathrm{Fe}_{2} \mathrm{O}_{3}-\mathrm{Al}_{2} \mathrm{O}_{3}$ sample) samples at $673 \mathrm{~K}$. The data are shown in Figure 8. The regions between the dashed lines in the figure correspond to periods of time during which $10 \% \mathrm{O}_{2}(\mathrm{~m} / \mathrm{e}=32), 10 \% \mathrm{CO}(\mathrm{m} / \mathrm{e}=28)$, or pure $\mathrm{He}$ was passing over the catalyst. The observation of $\mathrm{CO}_{2}(\mathrm{~m} / \mathrm{e}=28,44)$ upon exposure of the catalyst to $\mathrm{CO}$ is due to reduction of the catalyst and the reducibility can be calculated from the 
amount of $\mathrm{CO}_{2}$ that is formed. It is qualitatively apparent that less reduction occurred in the 1 wt.\% $\mathrm{Pd} / \mathrm{Al}_{2} \mathrm{O}_{3}$ sample, Figure 8(a) than in the 1 wt. $\% \mathrm{Pd} / 20 \mathrm{Fe}_{2} \mathrm{O}_{3}-\mathrm{Al}_{2} \mathrm{O}_{3}$ sample, Figure 8(b). Based on the amount of $\mathrm{CO}_{2}$ produced during the reduction cycles, $90 \mu \mathrm{mol}$ of atomic oxygen could be reversibly removed per gram of catalyst on 1 wt. $\% \mathrm{Pd} / \mathrm{Al}_{2} \mathrm{O}_{3}, 380 \mu \mathrm{mol} / \mathrm{g}$ on 1 wt.\% $\mathrm{Pd} / 20 \mathrm{Fe}_{2} \mathrm{O}_{3}-\mathrm{Al}_{2} \mathrm{O}_{3}$, and $310 \mu \mathrm{mol} / \mathrm{g}$ on 1 wt. $\% \mathrm{Pd} / \mathrm{Fe}_{2} \mathrm{O}_{3}(\mathrm{IMP}) / \mathrm{Al}_{2} \mathrm{O}_{3}$. Theoretically, 1 wt. $\%$ $\mathrm{Pd} / \mathrm{Al}_{2} \mathrm{O}_{3}$ sample can give up $94 \mu \mathrm{mol} / \mathrm{g}$ of atomic oxygen by reduction of $\mathrm{PdO}$, in reasonable agreement with the experimental results. Bulk reduction of $\mathrm{Fe}_{2} \mathrm{O}_{3}$ to $\mathrm{Fe}_{3} \mathrm{O}_{4}$ would yield 2100 $\mu \mathrm{mol} / \mathrm{g}$ of oxygen, so that the $20 \mathrm{Fe}_{2} \mathrm{O}_{3}-\mathrm{Al}_{2} \mathrm{O}_{3}$ sample $\left(0.25 \mathrm{~g} \mathrm{Fe}_{2} \mathrm{O}_{3} / \mathrm{g} \mathrm{Al}_{2} \mathrm{O}_{3}\right)$ could provide 420 $\mu \mathrm{mol} / \mathrm{g}$ of oxygen from reduction of $\mathrm{Fe}_{2} \mathrm{O}_{3}$. Since the reduction conditions used in our measurements were relatively mild, it is not surprising that we did not achieve complete reduction of $\mathrm{Fe}_{2} \mathrm{O}_{3}$. The reduction of $\mathrm{Fe}_{2} \mathrm{O}_{3}(\mathrm{IMP}) / \mathrm{Al}_{2} \mathrm{O}_{3}$, with a similar $\mathrm{Fe}_{2} \mathrm{O}_{3}$ loading, was weaker, most likely because of the poor interfacial contact between $\mathrm{Pd}$ and $\mathrm{Fe}_{2} \mathrm{O}_{3}$. The experiments demonstrate that a very large fraction of the $\mathrm{Fe}_{2} \mathrm{O}_{3}$ from the film could be reduced when $\mathrm{Pd}$ was in good contact with $\mathrm{Fe}_{2} \mathrm{O}_{3}$.

\section{Discussion:}

The work here demonstrates that ALD can be used to prepare high-surface-area, functional oxides for application to porous, catalytic materials. The $\mathrm{Fe}_{2} \mathrm{O}_{3}$ deposited on $\mathrm{Al}_{2} \mathrm{O}_{3}$ in the present study appears to form dense, conformal films. The fact that the films remain invisible to XRD to very high temperatures, even for loadings greater than $40 \mathrm{wt}$. $\% \mathrm{Fe}_{2} \mathrm{O}_{3}$, suggests that these films are also thermally stable. The low specific rates we observed for the water-gas-shift (WGS) reaction seem to indicate that the structure and properties of ALD-prepared oxide films can be different from that of the bulk oxides. However, given that commercial WGS catalysts are promoted with additional additives, it is very likely that the thin film oxides could be modified to increase their activity. Finally, a comparison of the present results for ALD-grown $\mathrm{Fe}_{2} \mathrm{O}_{3}$ films on $\mathrm{Al}_{2} \mathrm{O}_{3}$ with previous results for $\mathrm{CeO}_{2}$ films on $\mathrm{Al}_{2} \mathrm{O}_{3}$ [19] and $\mathrm{ZrO}_{2}$ films on $\mathrm{Al}_{2} \mathrm{O}_{3}$ [20] and $\mathrm{CeO}_{2}$ [24] implies that the application of ALD for preparing conformal oxide films is applicable for a wide range of materials.

It is important to recognize that the methods used in performing ALD can result in very different types of materials when the substrate is porous. Most previous studies have used an inert carrier gas to provide contact between the substrate and the organometallic precursor [21]. 
Because gas-phase diffusion is a relatively slow process, this can result in concentration gradients. For non-porous powders, these concentration gradients can be reduced by performing the ALD in a fluidized bed [31]; however, most of the surface area in catalytic materials exists within small pores and gradients in these pores cannot be removed by fluidization. Exposing the substrate to the precursor and oxidant under static conditions largely eliminates these problems and allows the use of relatively large, high-surface-area samples. Static conditions also minimize the loss of potentially expensive organometallic precursor, since essentially all the precursor is used in the films and very little is lost during the evacuation cycle.

The nature of the oxide films is also different depending on how ALD is performed. Some previous reports of ALD films grown in porous materials have shown that the oxide films were porous [32,33]. While the production of nanopores may be desirable [34,35], it is clearly important to control the process. Exactly why ALD films are sometimes porous is uncertain and may not always be the same. Simple shrinkage of low-density films is likely responsible for pores in many cases. However, in at least one example where porous $\mathrm{ZrO}_{2}$ films were produced, the observed growth rates were unexpectedly high, greater than $0.5-\mathrm{nm}$ per cycle [33]. Using the same organometallic precursor, the $\mathrm{ZrO}_{2}$ growth rate observed by some of us on $\mathrm{CeO}_{2}$ [24] and $\mathrm{Al}_{2} \mathrm{O}_{3}$ [30] substrates was only $0.02 \mathrm{~nm}$ per cycle. It is unlikely that the higher growth rate was due to chemical vapor deposition (CVD), since the deposition temperature was not high and CVD would likely have resulted in thicker films near the external surface of the sample. An alternative possible explanation is that excess precursor may condense on the porous substrate and then not be completely removed prior to the oxidation cycle due to slow diffusion of the precursor in the inert carrier. The exact reason for differences in the oxide-film morphologies remains unknown but the differences clearly demonstrate the need for a better understanding of the processes involved for ALD in porous materials.

The high thermal stability of oxide films prepared by ALD was reported previously for $\mathrm{CeO}_{2}$ [19] and $\mathrm{ZrO}_{2}$ [20] films and was again observed here for $\mathrm{Fe}_{2} \mathrm{O}_{3}$ on $\mathrm{Al}_{2} \mathrm{O}_{3}$. In part, this is due to the relatively lower surface energy of oxides compared to metals. There may also be attractive interactions between the substrate and film. Assuming that is the case, it would be interesting to explore the effect of substrate composition on the stability and properties of the films. It may even be desirable to grow multiple layers with different compositions. For example, $\mathrm{Fe}_{2} \mathrm{O}_{3}$ layers could be grown on $\mathrm{CeO}_{2} / \mathrm{Al}_{2} \mathrm{O}_{3}$ substrates in which the $\mathrm{CeO}_{2}$ was grown by ALD. 
These multilayer systems may allow one to build in specific chemical interactions between various oxides.

We regard the use of ALD for catalyst preparation as still in its early stages. There are obviously many ways in which it can be applied and the preparation of high-surface-area functional oxides is only one of those. Given the flexibility for preparing a range of interesting materials, ALD could be widely applied for producing novel catalytic materials.

\section{Conclusions:}

The growth of $\mathrm{Fe}_{2} \mathrm{O}_{3}$ films by ALD on high-surface-area $\gamma-\mathrm{Al}_{2} \mathrm{O}_{3}$ was studied in a static system. The sample mass was found to increase almost linearly with the number of ALD cycles at lower coverages, with a growth rate corresponding to $0.016 \mathrm{~nm}$ per cycle. Surface-area and pore-size-distribution measurements, along with TEM-EDS mapping, were consistent with formation of dense, conformal films on the $\mathrm{Al}_{2} \mathrm{O}_{3}$. The catalytic properties for the water-gas-shift reaction were different from that of bulk $\mathrm{Fe}_{2} \mathrm{O}_{3}$ but the films were reducible and could be promoted to provide high activity by addition of $\mathrm{Pd}$. The results demonstrate that ALD can be an important tool for catalyst synthesis.

\section{Acknowledgements:}

TMO and RJG are grateful to the Department of Energy, Office of Basic Energy Sciences, Chemical Sciences, Geosciences and Biosciences Division, Grant No. DE-FG0213ER16380 for support of this work. SZ, SD, GWG, and XP are grateful to the National Science Foundation for their support through Grants CBET-1159240 and DMR-0723032. 
$\underline{\text { Abstract Figure: }}$

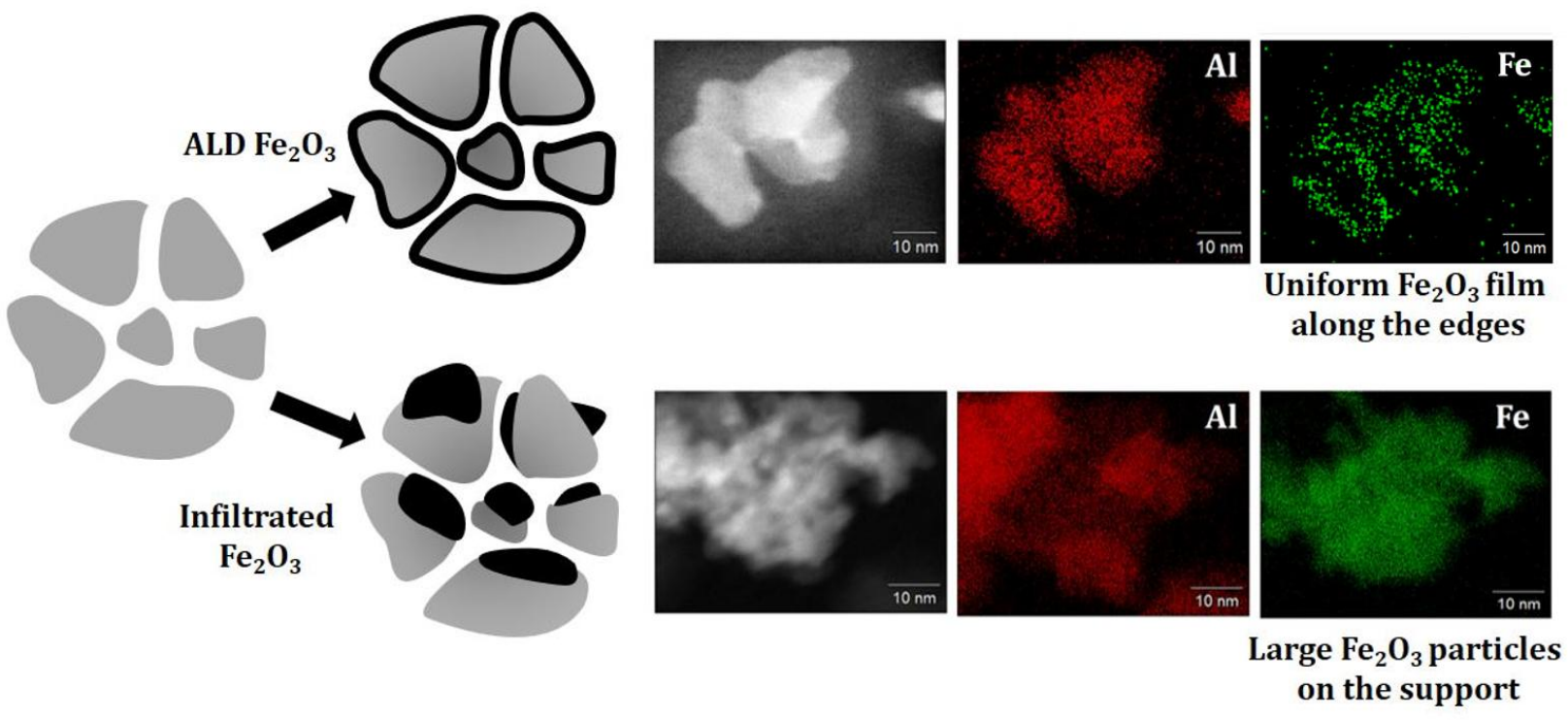




\section{Figure Captions:}

Figure 1: (a) Mass change and (b) BET surface area as a function of the number of $\mathrm{Fe}_{2} \mathrm{O}_{3}$ ALD cycles on $\gamma-\mathrm{Al}_{2} \mathrm{O}_{3}$ after calcination to $773 \mathrm{~K}$. The surface areas in the two open symbols were measured after calcining the samples to $1073 \mathrm{~K}$.

Figure 2: $\quad$ Pore-size distributions determined from $\mathrm{N}_{2}$ adsorption isotherms on (a) the $\gamma$ $\mathrm{Al}_{2} \mathrm{O}_{3}$ support, (b) $10 \mathrm{Fe}_{2} \mathrm{O}_{3}-\mathrm{Al}_{2} \mathrm{O}_{3}$ (c) $20 \mathrm{Fe}_{2} \mathrm{O}_{3}-\mathrm{Al}_{2} \mathrm{O}_{3}$, and (d) $40 \mathrm{Fe}_{2} \mathrm{O}_{3}-\mathrm{Al}_{2} \mathrm{O}_{3}$ after calcination at $773 \mathrm{~K}$ and $1073 \mathrm{~K}$.

Figure 3: $\quad \mathrm{XRD}$ patterns of (a) the $\gamma-\mathrm{Al}_{2} \mathrm{O}_{3}$ support after heating to $1173 \mathrm{~K}$ and two ALDcoated samples after calcination to $1073 \mathrm{~K}$ : (b) $20 \mathrm{Fe}_{2} \mathrm{O}_{3}-\mathrm{Al}_{2} \mathrm{O}_{3}$ and (c) $100 \mathrm{Fe}_{2} \mathrm{O}_{3^{-}}$ $\mathrm{Al}_{2} \mathrm{O}_{3}$. The pattern in (d) was obtained on $\mathrm{Fe}_{2} \mathrm{O}_{3}(\mathrm{IMP}) / \mathrm{Al}_{2} \mathrm{O}_{3}$ with the same $\mathrm{Fe}_{2} \mathrm{O}_{3}$ loading as $100 \mathrm{Fe}_{2} \mathrm{O}_{3}-\mathrm{Al}_{2} \mathrm{O}_{3}$ heated to $1073 \mathrm{~K}$. Characteristic peaks for hematite, $\alpha-\mathrm{Fe}_{2} \mathrm{O}_{3}$, are shown by the bold lines and marked by *.

Figure 4: $\quad$ High angle annular dark field STEM image of (a) $\mathrm{Fe}_{2} \mathrm{O}_{3}$ (IMP)/ $/ \mathrm{Al}_{2} \mathrm{O}_{3}(0.25 \mathrm{~g}$ $\mathrm{Fe}_{2} \mathrm{O}_{3} / \mathrm{g} \mathrm{Al}_{2} \mathrm{O}_{3}$ ) and (b) $20 \mathrm{Fe}_{2} \mathrm{O}_{3}-\mathrm{Al}_{2} \mathrm{O}_{3}$ after calcination at $773 \mathrm{~K}$. EDS mapping of $\mathrm{Al}, \mathrm{O}$, and $\mathrm{Fe}$ shows rich Fe signals on the edges on the ALD-modified $\mathrm{Al}_{2} \mathrm{O}_{3}$ support, while there was no preferential distribution of $\mathrm{Fe}$ on the impregnated sample.

Figure 5: $\quad$ Raman spectra of various $\mathrm{Fe}_{2} \mathrm{O}_{3} / \mathrm{Al}_{2} \mathrm{O}_{3}$ supports: (a) $10 \mathrm{Fe}_{2} \mathrm{O}_{3}-\mathrm{Al}_{2} \mathrm{O}_{3}$, (b) $20 \mathrm{Fe}_{2} \mathrm{O}_{3}-$ $\mathrm{Al}_{2} \mathrm{O}_{3}$, and (c) $40 \mathrm{Fe}_{2} \mathrm{O}_{3}-\mathrm{Al}_{2} \mathrm{O}_{3}$ and (d) $\mathrm{Fe}_{2} \mathrm{O}_{3}$ (IMP)/ $/ \mathrm{Al}_{2} \mathrm{O}_{3}\left(0.25 \mathrm{~g} \mathrm{Fe}_{2} \mathrm{O}_{3} / \mathrm{g} \mathrm{Al}_{2} \mathrm{O}_{3}\right.$ ). All samples were calcined to $773 \mathrm{~K}$.

Figure 6: Steady-state, differential reaction rates for the water-gas-shift (WGS) reaction with partial pressures of 25 Torr $\mathrm{CO}$ and 25 Torr $\mathrm{H}_{2} \mathrm{O}$ : $(\boldsymbol{\bullet})-10 \mathrm{Fe}_{2} \mathrm{O}_{3}-\mathrm{Al}_{2} \mathrm{O}_{3} ;(\bullet)$ $-40 \mathrm{Fe}_{2} \mathrm{O}_{3}-\mathrm{Al}_{2} \mathrm{O}_{3} ;(\boldsymbol{\Delta})$ - bulk $\mathrm{Fe}_{2} \mathrm{O}_{3}$; and (口) - $\mathrm{Fe}_{2} \mathrm{O}_{3}(\mathrm{IMP}) / \mathrm{Al}_{2} \mathrm{O}_{3}\left(0.13 \mathrm{~g} \mathrm{Fe}_{2} \mathrm{O}_{3} / \mathrm{g}\right.$ $\mathrm{Al}_{2} \mathrm{O}_{3}$ ). The rates were normalized to the BET surface areas and all catalysts were calcined to $773 \mathrm{~K}$. The uncertainty of the temperature is within $\pm 5 \mathrm{~K}$ for our experimental setup, while the uncertainty of the TOF is less $5 \%$ for measurements on multiple samples.

Figure 7: $\quad$ Steady-state, differential reaction rates for the water-gas-shift (WGS) reaction with partial pressures of 25 Torr $\mathrm{CO}$ and 25 Torr $\mathrm{H}_{2} \mathrm{O}$ after addition of $1 \mathrm{wt}$ \% Pd. Rates were measured after calcination to (a) $773 \mathrm{~K}$ or (b) $1073 \mathrm{~K}$ : (•) $\mathrm{Pd} / 20 \mathrm{Fe}_{2} \mathrm{O}_{3}-\mathrm{Al}_{2} \mathrm{O}_{3},(\boldsymbol{\Delta})-\mathrm{Pd} / \mathrm{Fe}_{2} \mathrm{O}_{3}$, ( $) \mathrm{Pd} / \mathrm{Fe}_{2} \mathrm{O}_{3}(\mathrm{IMP}) / \mathrm{Al}_{2} \mathrm{O}_{3}\left(0.25 \mathrm{~g} \mathrm{Fe}_{2} \mathrm{O}_{3} / \mathrm{g}\right.$ $\left.\mathrm{Al}_{2} \mathrm{O}_{3}\right)$, and $(\bullet)-\mathrm{Pd} / \mathrm{Al}_{2} \mathrm{O}_{3}$. The uncertainty of the temperature is within $\pm 5 \mathrm{~K}$ for our experimental setup, while the uncertainty of the TOF is less than $5 \%$ for measurements on multiple samples.

Figure 8: $\quad \mathrm{CO}-\mathrm{O}_{2}$ pulse measurements on a) 1 wt. $\% \mathrm{Pd} / \mathrm{Al}_{2} \mathrm{O}_{3}$, b) 1 wt. $\% \mathrm{Pd} / 20 \mathrm{Fe}_{2} \mathrm{O}_{3}-\mathrm{Al}_{2} \mathrm{O}_{3}$, and c) $1 \mathrm{wt} \% \mathrm{Pd} / \mathrm{Fe}_{2} \mathrm{O}_{3}(\mathrm{IMP}) / \mathrm{Al}_{2} \mathrm{O}_{3}$ at $673 \mathrm{~K}$. The loading of $\mathrm{Fe}_{2} \mathrm{O}_{3}$ for the ALDmodified and impregnated samples were $0.25 \mathrm{~g} \mathrm{Fe}_{2} \mathrm{O}_{3} / \mathrm{g} \mathrm{Al}_{2} \mathrm{O}_{3}$. The data shows $\mathrm{CO}(\mathrm{m} / \mathrm{e}=28), \mathrm{O}_{2}(\mathrm{~m} / \mathrm{e}=32)$, and $\mathrm{CO}_{2}(\mathrm{~m} / \mathrm{e}=28,44)$ pulses. 
Figure 1:
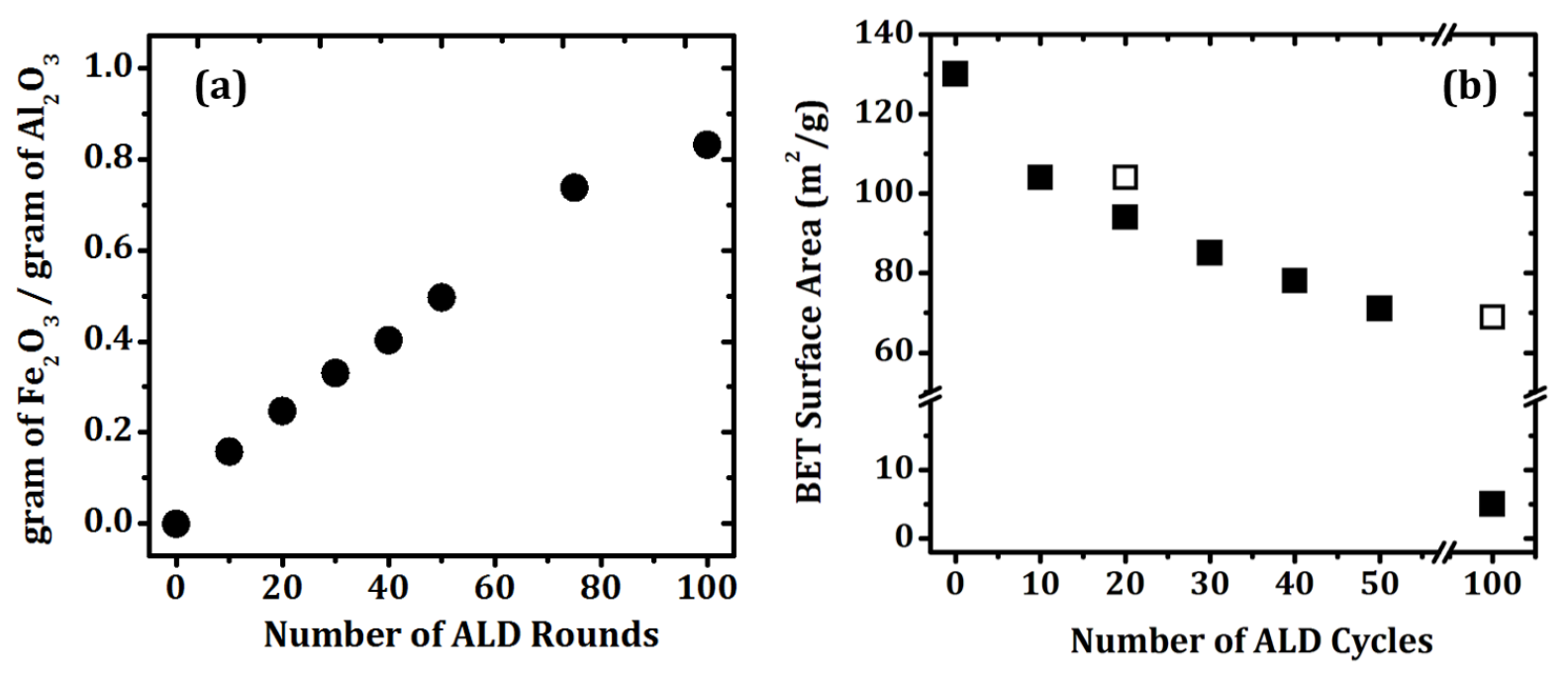
Figure 2:

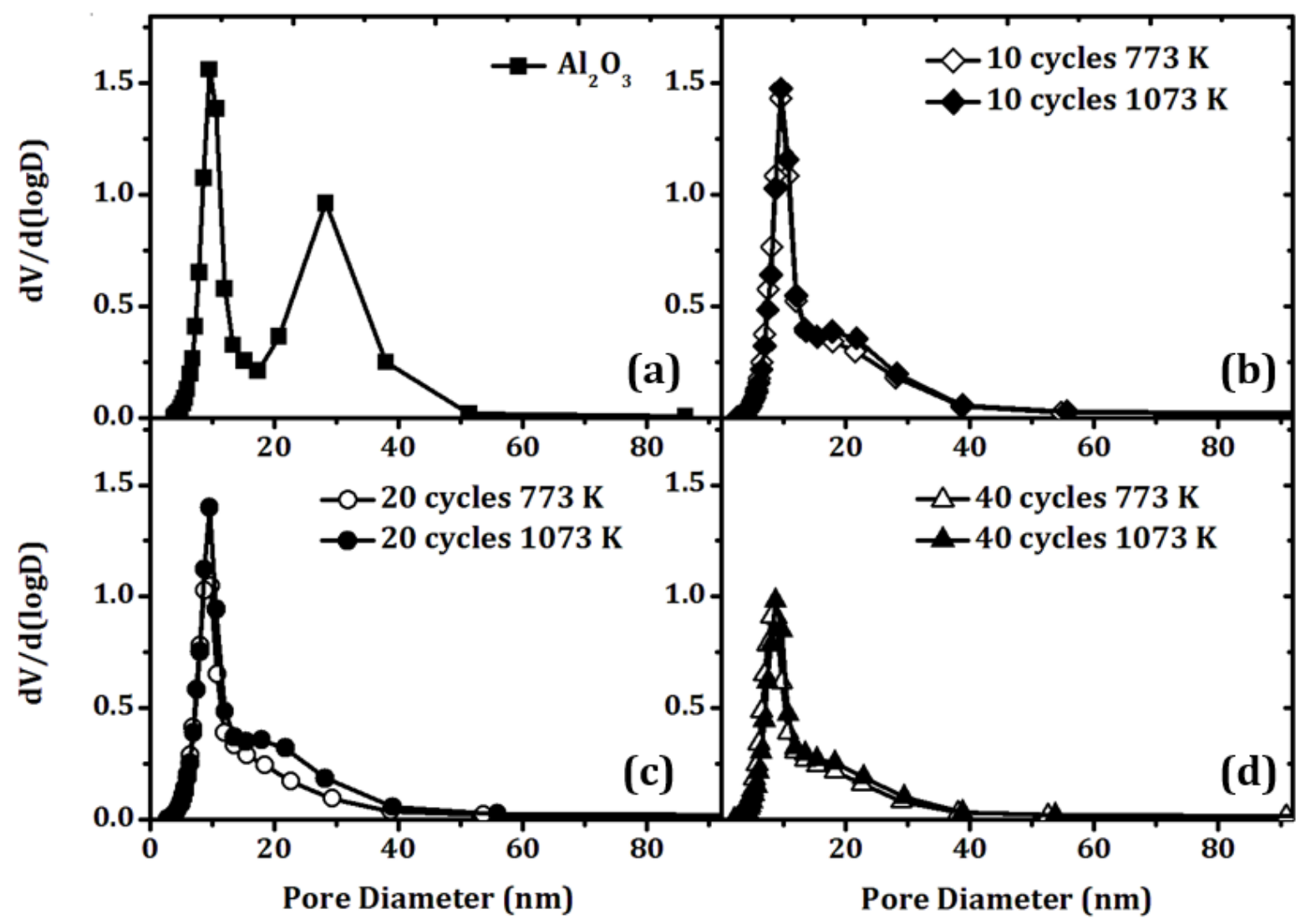


Figure 3:

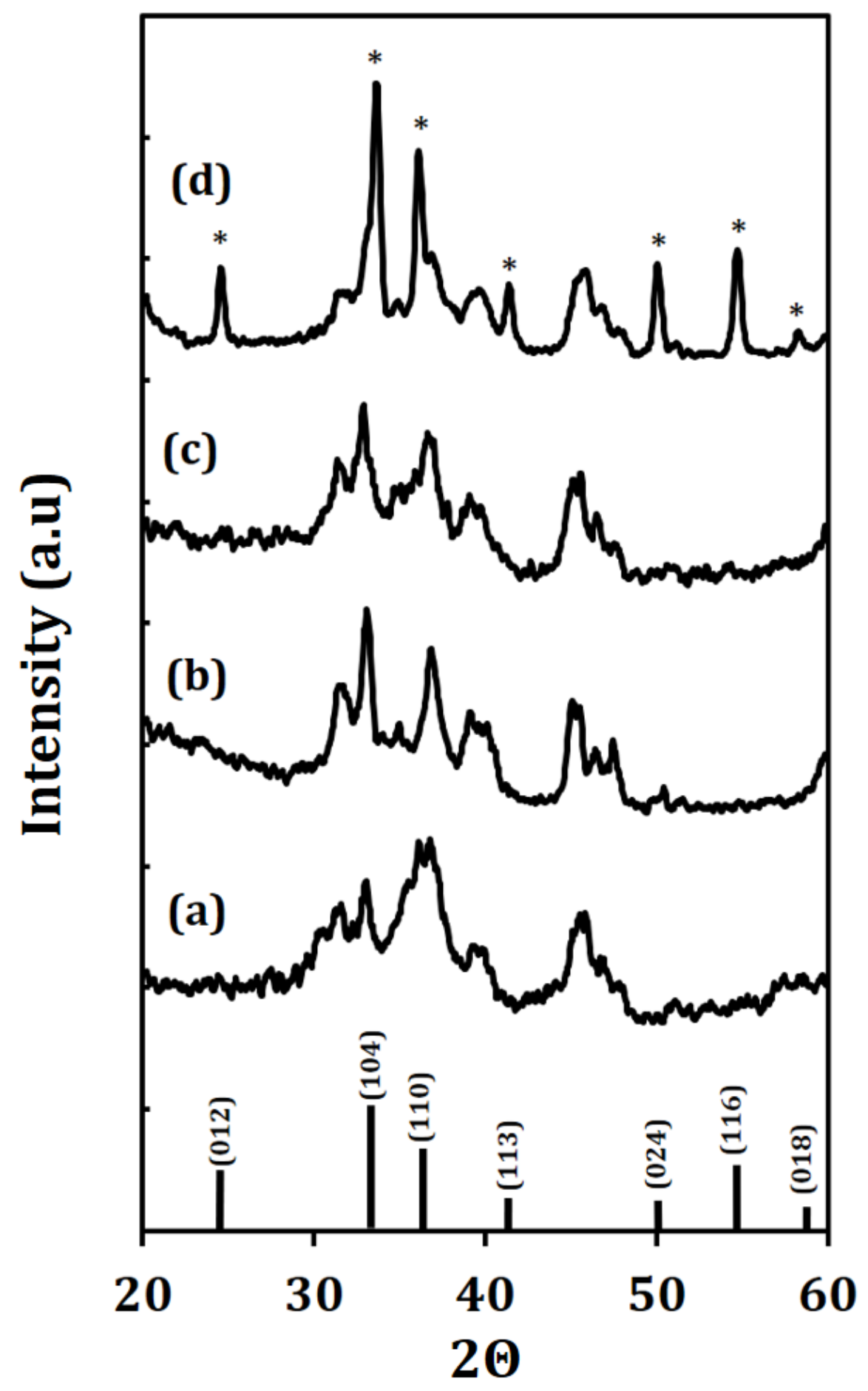


Figure 4:
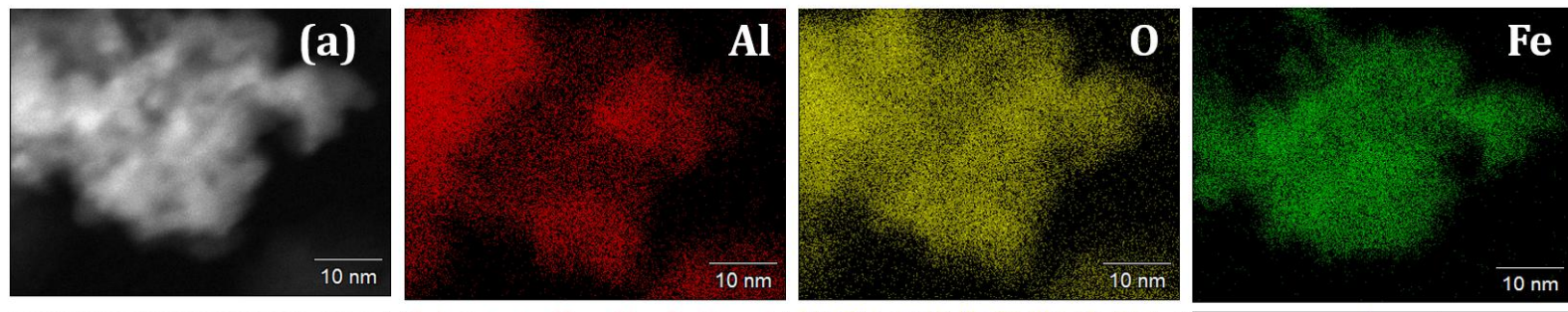

(b)
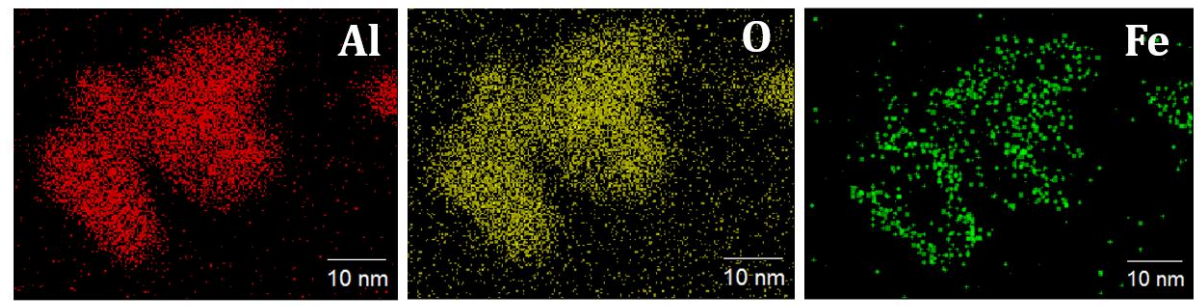
Figure 5:

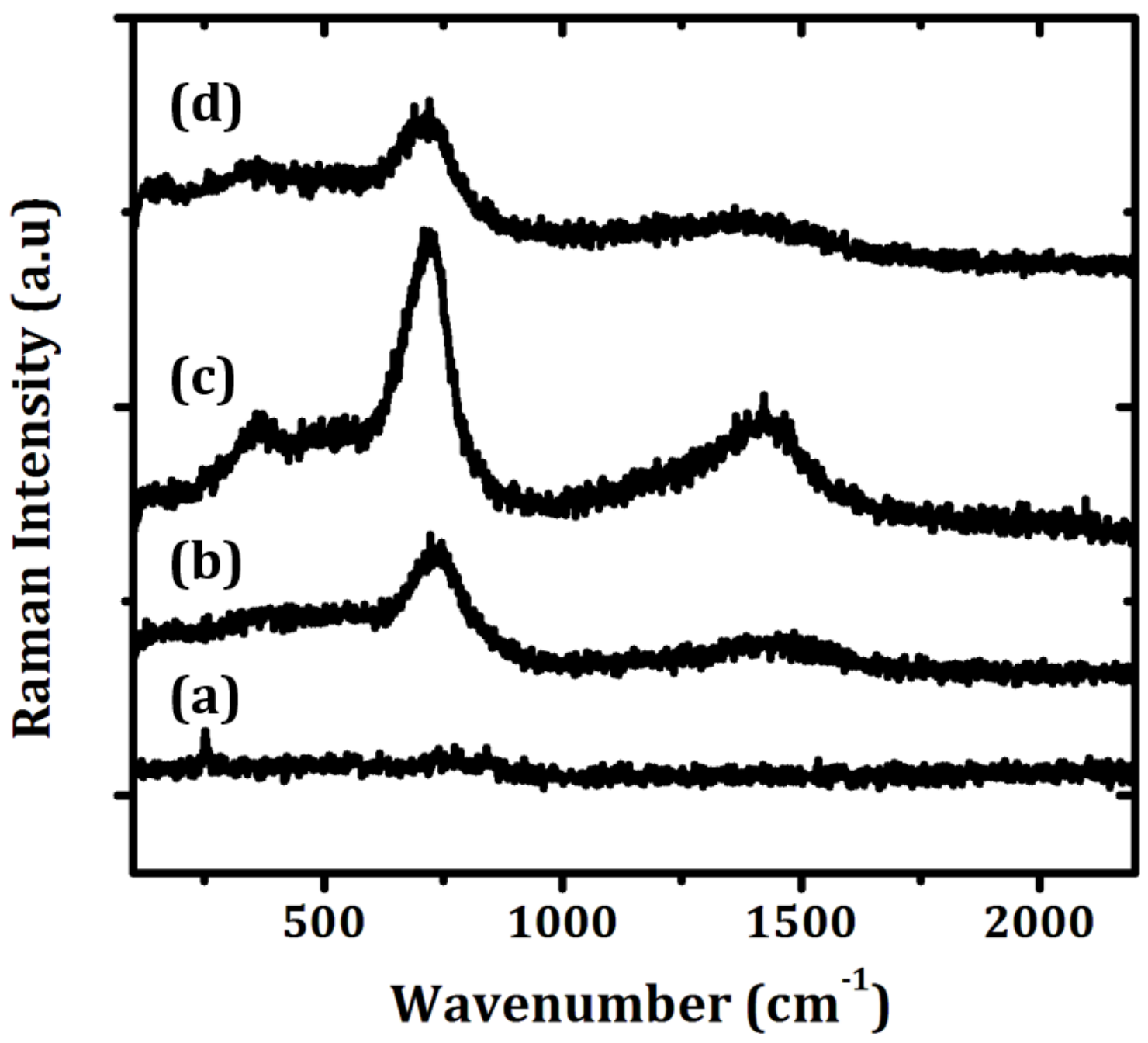


Figure 6:

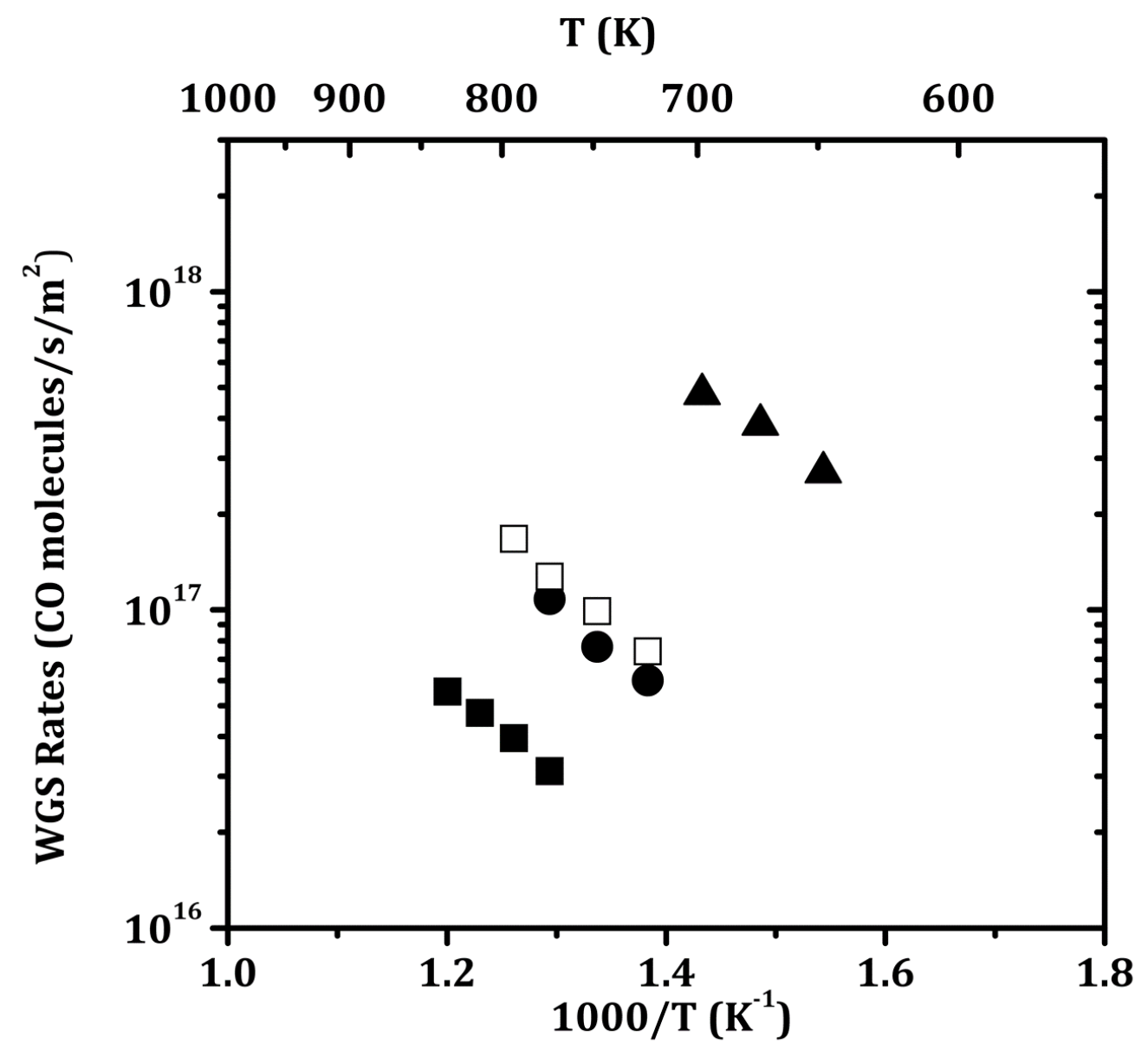


Figure 7:
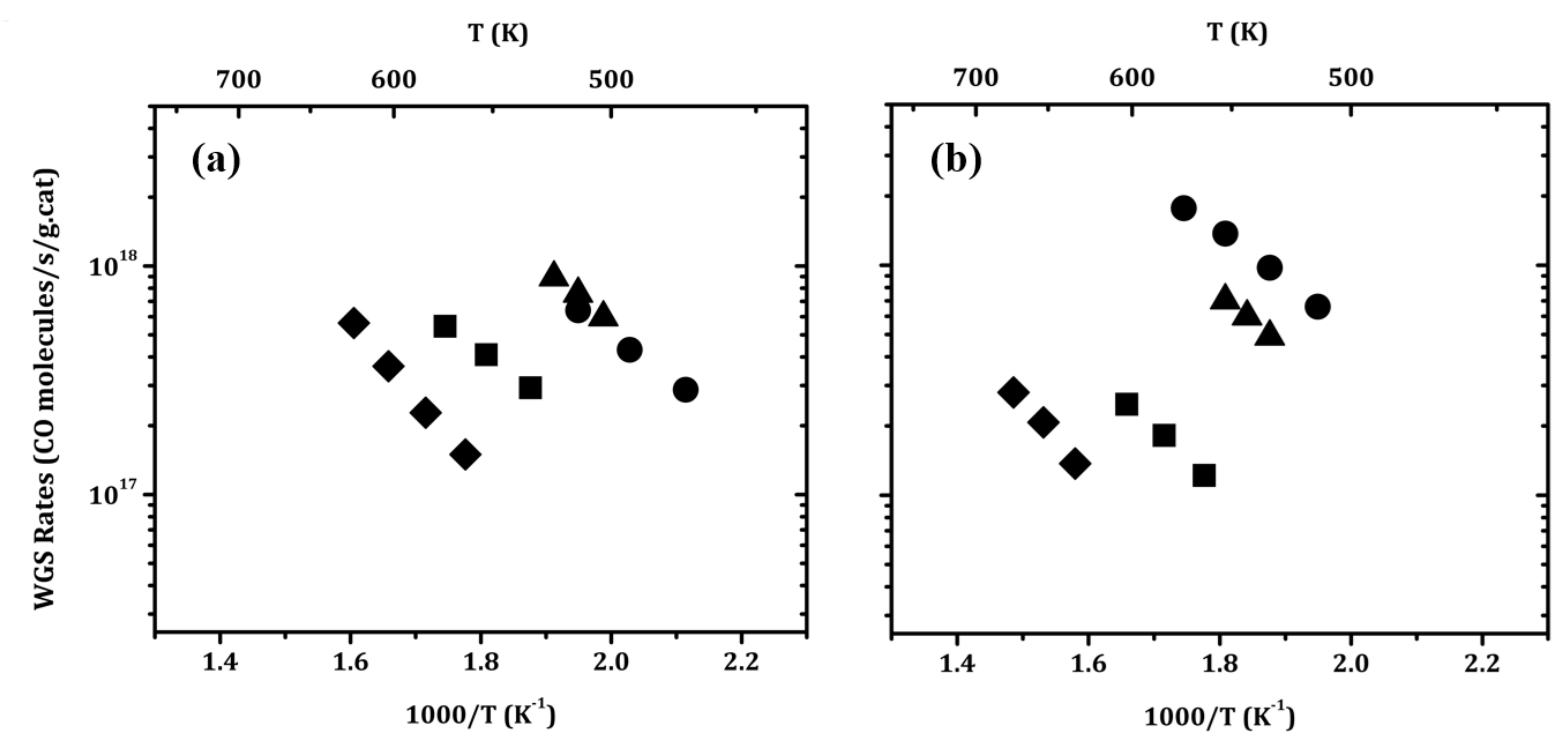
Figure 8:
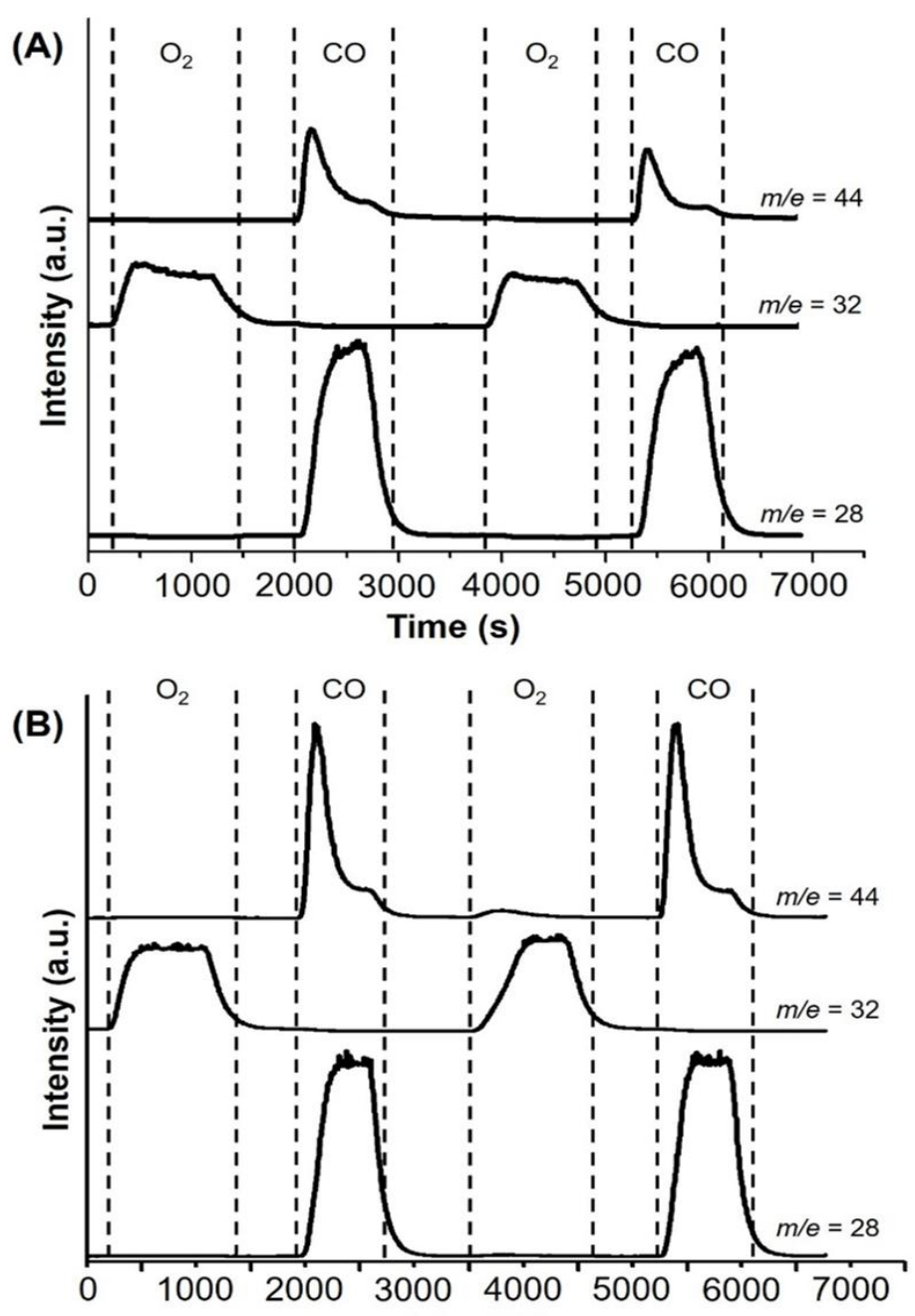

Time (s)

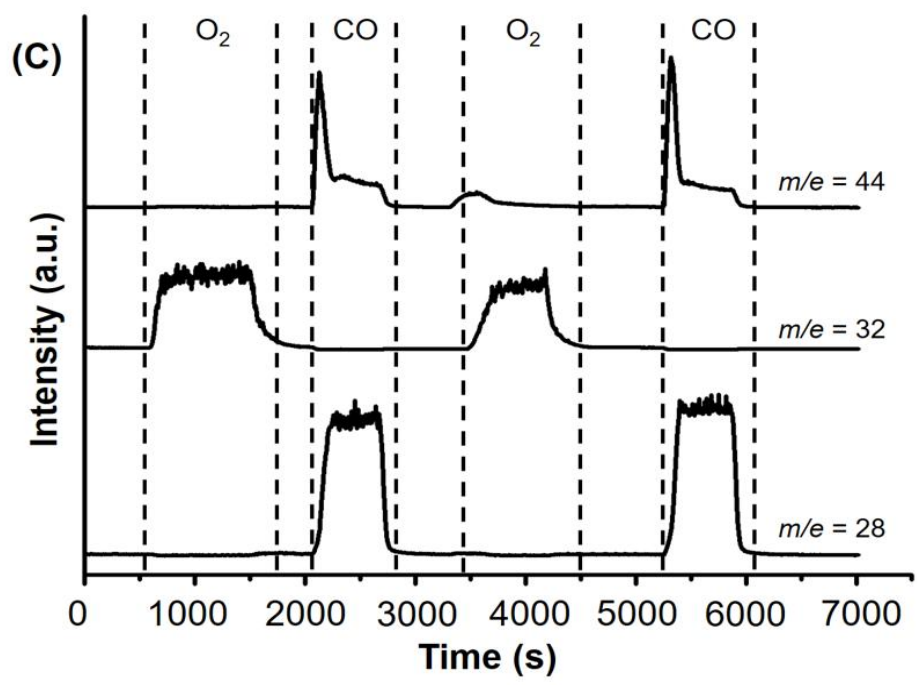


Table 1: Pore Size from $\mathrm{N}_{2}$ Isotherm in the Mesopore Region as a function of ALD Cycles after the samples were heated to $773 \mathrm{~K}$.

\begin{tabular}{|c|c|}
\hline Number of ALD Cycles & Mesopore Size (nm) \\
\hline 0 & 9.6 \\
\hline 10 & 9.6 \\
\hline 20 & 9.3 \\
\hline 40 & 8.5 \\
\hline
\end{tabular}

Table 2: Steady-state, water-gas-shift activity normalized to BET surface area for bulk $\mathrm{Fe}_{2} \mathrm{O}_{3}$ support as a function of calcination temperature.

\begin{tabular}{|c|c|c|}
\hline $\begin{array}{c}\text { Calcination } \\
\text { Temperature (K) }\end{array}$ & $\begin{array}{c}\text { BET Surface Area } \\
\left(\mathbf{m}^{\mathbf{2}} / \mathbf{g}\right)\end{array}$ & $\begin{array}{c}\text { WGS Activity per area } \\
\text { at } \mathbf{6 7 3} \mathbf{~ K}\end{array}$ \\
\hline 773 & 41 & 4 \\
\hline 1073 & 2 & 40 \\
\hline
\end{tabular}


Table 3: Dispersion Measurement as a function of Calcination Temperature.

\begin{tabular}{|c|c|c|c|}
\hline $\begin{array}{c}\text { Calcination } \\
\text { Temperature (K) }\end{array}$ & $\mathbf{P d} / \mathbf{2 0} \mathbf{F e}_{\mathbf{2}} \mathbf{O}_{\mathbf{3}}-\mathbf{A l}_{\mathbf{2}} \mathbf{O}_{\mathbf{3}}$ & $\mathbf{P d} / \mathbf{F e}_{\mathbf{2}} \mathbf{O}_{\mathbf{3}}$ & $\mathbf{P d} / \mathbf{F e}_{\mathbf{2}} \mathbf{O}_{\mathbf{3}}(\mathbf{I M P}) / \mathbf{A l}_{\mathbf{2}} \mathbf{O}_{\mathbf{3}}$ \\
\hline 773 & 13 & 9 & 16 \\
\hline 1073 & 11 & 2 & 7 \\
\hline
\end{tabular}




\section{Citations:}

1. H.-W. Jen, G. Graham, W. Chun, R. McCabe, J.-P. Cuif, S. Deutsch, O. Touret, , Catal. Today 50 (1999) 309-328.

2. M. Sugiura, Catal. Surv. from Asia 7 (2003) 77-87.

3. C. Rhodes, G.J. Hutchings, Phys. Chem. Chem. Phys. 5 (2003) 2719-2723.

4. L. Zhang, X. Wang, J.-M.M. Millet, P.H. Matter, U.S. Ozkan, Appl. Catal. A: Gen. 351 (2008) 1-8.

5. A. Basińska, A. Nowacki, F. Domka, React. Kinet. and Catal. Lett. 66 (1999) 3-11.

6. A. Basińska, F. Domka, Catal. Lett. 17 (1993) 327-332.

7. S. Zhao, R.J. Gorte, Catal. Lett. 92 (2004) 75-80.

8. N. Mimura, I. Takahara, M. Saito, T. Hattori, K. Ohkuma, M. Ando, Catal. Today 45 (1998) 61-64.

9. T. Mattisson, A. Lyngfelt, P. Cho, Fuel. 80 (2001) 1953-1962.

10. M.A. Uddin, H. Tsuda, S. Wu, E. Sasaoka, Fuel. 87 (2008) 451-459.

11. B. Zhang, X.-W. Guo, H. Liang, H. Ge, X. Gu, S. Chen, H. Yang, Y. Qin, ACS Catal. 6 (2016) 6560-6566.

12. G. Carraro, D. Barreca, M. Cruz- Yusta, A. Gasparotto, C. Maccato, J. Morales, C. Sada, L. Sánchez, ChemPhysChem. 13 (2012) 3798-3801.

13. G. Carraro, D. Barreca, E. Comini, A. Gasparotto, C. Maccato, C. Sada, G. Sberveglieri, CrystEngComm. 14 (2012) 6469-6476.

14. M.E.A. Warwick, K. Kaunisto, D. Barreca, G. Carraro, A. Gasparotto, C. Maccato, E. Bontempi, C. Sada, T.-P. Ruoko, S. Turner, ACS Appl. Mater. \& Interfaces. 7 (2015) 86678676.

15. B.J.-J. He, C.-X. Wang, T.-T. Zheng, Y.-K. Zhao, Johns. Matthey Technol. Rev. 60 (2016) 196-203.

16. C. Ratnasamy, J.P. Wagner, Catal. Rev. 51 (2009) 325-440.

17. I. Baldychev, J.M. Vohs, R.J. Gorte, Appl. Catal. A: Gen. 356 (2009) 225-230.

18. T. Popa, G. Xu, T.F. Barton, M.D. Argyle, Appl. Catal. A: Gen.379 (2010) 15-23. 
19. T.M. Onn, S. Zhang, L. Arroyo-Ramirez, Y. Xia, C. Wang, X. Pan, G.W. Graham, R.J. Gorte, Appl. Catal. B: Environ. 201 (2017) 430-437.

20. T.M. Onn, S. Zhang, L. Arroyo-Ramirez, Y.-C. Chung, G.W. Graham, X. Pan, R.J. Gorte, ACS Catal. 5 (2015) 5696-5701.

21. B.J. O’Neill, D.H. Jackson, J. Lee, C. Canlas, P.C. Stair, C.L. Marshall, J.W. Elam, T.F. Kuech, J.A. Dumesic, G.W. Huber, ACS Catal. 5 (2015) 1804-1825.

22. J. Lu, J.W. Elam, P.C. Stair, Surf. Sci. Rep. 71 (2016) 410-472.

23. S.Y. Anthony, R. Küngas, J.M. Vohs, R.J. Gorte, J. of the Electrochem. Soc. 160 (2013) F1225-F1231.

24. T.M. Onn, L. Arroyo-Ramirez, M. Monai, T.-S. Oh, M. Talati, P. Fornasiero, R.J. Gorte, M.M. Khader, Appl. Catal. B: Environ. 197 (2015) 280-285.

25. A.B. Martinson, M.J. DeVries, J.A. Libera, S.T. Christensen, J.T. Hupp, M.J. Pellin, J.W. Elam, The J. of Phys. Chem. C, 115 (2011) 4333-4339.

26. T. Luo, R.J. Gorte, Appl. Catal. B: Environ. 53 (2004) 77-85.

27. M. Rooth, A. Johansson, K. Kukli, J. Aarik, M. Boman, A. Hårsta, Chem. Vap. Depos. 14 (2008) 67-70.

28. P. Colomban, S. Cherifi, G. Despert, J. of Raman Spectrosc. 39 (2008) 881-886.

29. M. Hanesch, Geophys. J. Int. 177 (2009) 941-948.

30. M. Zhu, I.E. Wachs, ACS Catal. 6 (2015) 722-732.

31. D.M. King, J.A. Spencer, X. Liang, L.F. Hakim, A.W. Weimer, Surf. and Coat. Technol. 201 (2007) 9163-9171.

32. T. Li, S. Karwal, B. Aoun, H. Zhao, Y. Ren, C.P. Canlas, J.W. Elam, R.E. Winans, Chem. of Mater. 28 (2016) 7082-7087.

33. Y. Chen, K. Gerdes, X. Song, Sci. Rep. 6 (2016).

34. J. Lu, B. Fu, M.C. Kung, G. Xiao, J.W. Elam, H.H. Kung, P.C. Stair, Sci. 335 (2012) 12051208.

35. B.J. O'Neill, D.H. Jackson, A.J. Crisci, C.A. Farberow, F. Shi, A.C. Alba- Rubio, J. Lu, P.J. Dietrich, X. Gu, C.L. Marshall, Angew. Chem. 125 (2013) 14053-14057 
$\underline{\text { Abstract Figure: }}$

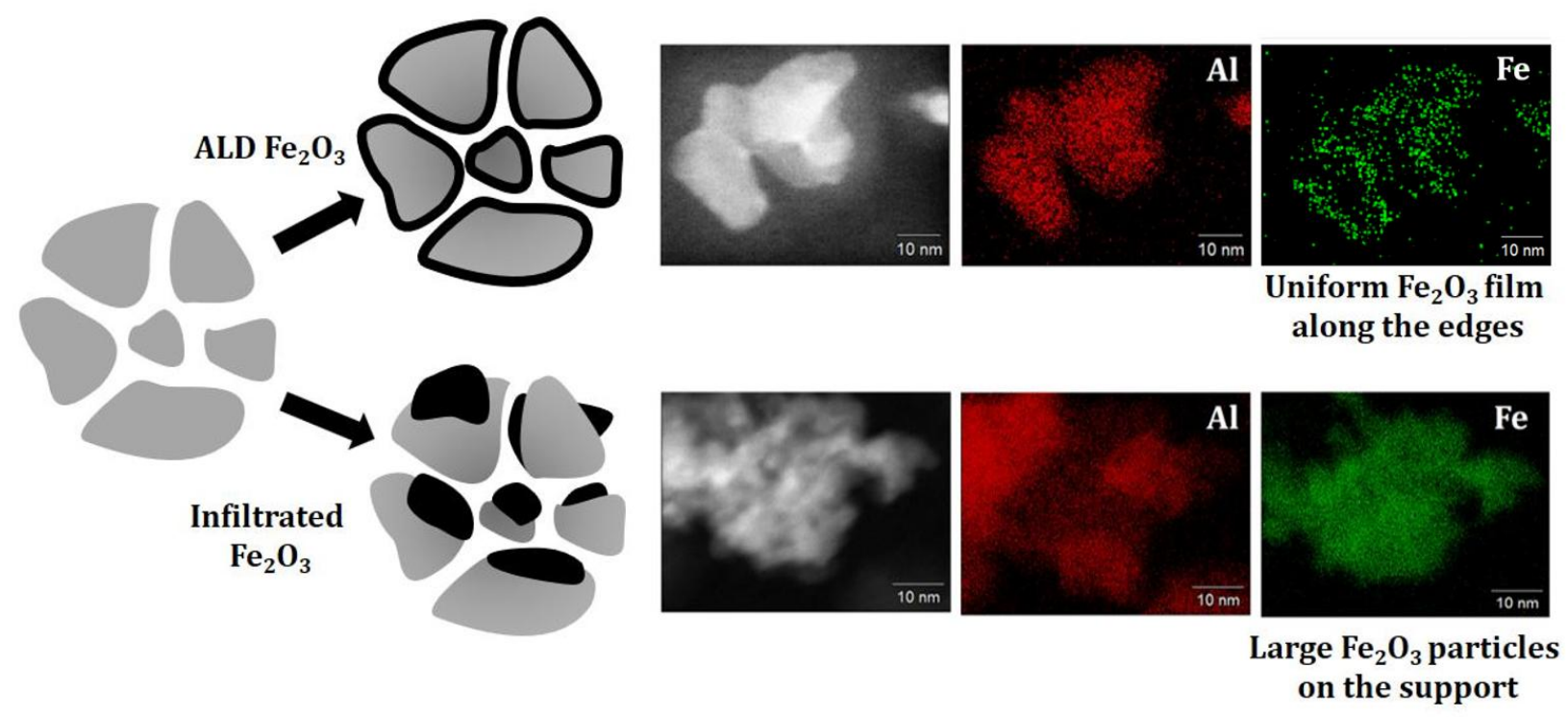

